\title{
ZWIĄZEK POLAKÓW NA BIALORUSI W POLSKIEJ POLITYCE ZAGRANICZNEJ W LATACH 2008-2010
}

\author{
WPROWADZENIE
}

W debacie publicznej po 1989 r. znacznie większe miejsce niż w okresie Polskiej Rzeczypospolitej Ludowej zajął temat Polaków, którzy w wyniku przesunięć granicznych podczas II wojny światowej stali się obywatelami Związku Socjalistycznych Republik Radzieckich. Wszystkie najważniejsze na scenie politycznej III Rzeczypospolitej środowiska dostrzegały potrzebę udzielania wsparcia polskim mniejszościom narodowym. Opieka nad nimi stała się istotnym celem prowadzonej przez kolejne rządy polityki zagranicznej wobec państw postradzieckich. Od początku lat 90. poszczególne gabinety wykluczały jednak możliwość uzależniania stosunków z Litwą, Białorusią oraz Ukrainą od warunków, jakie stwarzały żyjącym w ich granicach Polakom. W dyskursie publicznym dominowało bowiem przekonanie, iż mniejszości narodowe nie powinny stawać się przyczyną konfliktów w relacjach z sąsiednimi państwami. W stosunkach polsko-białoruskich założenie to uległo diametralnej zmianie w 2005 r. Sytuacja, w jakiej znalazła się wówczas polska mniejszość narodowa, stała się jednym z najpoważniejszych czynników utrudniających w kolejnych latach dobrosąsiedzkie kontakty. Powodem tego stanu stał się kryzys w Związku Polaków na Białorusi (ZPB).

ZPB powstał w 1990 r. jako organizacja mająca na celu podtrzymywanie tożsamości narodowej białoruskich obywateli pochodzenia polskiego. Poza prowadzeniem działalności kulturalno-oświatowej, w pierwszych latach istnienia związek, pod przewodnictwem Tadeusza Gawina, aktywnie uczestniczył w życiu politycznym państwa, współpracując z ugrupowaniami demokratycznymi. Po 1994 r. oznaczało to zaangażowanie polskiej organizacji w konflikt między reżimem Alek-

Dr AnNa WŁodarczyK - w latach 2009-2019 Zakład Stosunków Politycznych, Instytut Historii i Nauk Politycznych Uniwersytetu w Białymstoku; e-mail: annawlodarczyk117@gmail.com 
sandra Łukaszenki a zwalczającą go opozycją ${ }^{1}$. Konfrontacyjna wobec władz państwowych postawa, pod koniec lat 90. spotkała się z dezaprobatą wielu polskich działaczy. W 2000 r. nowym prezesem ZPB został Tadeusz Kruczkowski, który zapowiedział odejście od prowadzonej przez organizację działalności politycznej, zerwanie więzi z opozycją oraz podjęcie dialogu z władzami². Między zwolennikami Tadeusza Gawina oraz Tadeusza Kruczkowskiego wywiązał się spór na temat sposobu kierowania ZPB oraz miejsca tej organizacji na politycznej scenie Białorusi. W 2005 r. nastąpiła eskalacja tego konfliktu. W marcu do Grodna został zwołany VI Zjazd Delegatów ZPB w celu dokonania wyboru zarządu organizacji. Najpoważniejszymi kandydatami do objęcia stanowiska prezesa byli Tadeusz Kruczkowski oraz popierana przez grupę związaną z Tadeuszem Gawinem - Andżelika Borys. W elekcji, większością 56\% głosów, zwyciężyła Andżelika Borys³. Uczciwość dokonanego wyboru została zakwestionowana przez białoruskie Ministerstwo Sprawiedliwości, które 12 maja 2005 r. wydało decyzję o unieważnieniu VI Zjazdu Delegatów oraz nakazało jego powtórzenie. 27 sierpnia 2005 r. w Wołkowysku, pod kontrolą białoruskich władz państwowych, odbyło się ponowne głosowanie, w którego wyniku prezesem ZPB ogłoszono Józefa Łucznika ${ }^{4}$. Postanowienia te nie zostały zaakceptowane przez działaczy popierających A. Borys, którzy uznali ją za jedynego legalnego prezesa związku.

W zaistniały spór aktywnie włączyła się Warszawa, która od początku lat 90. udzielała wsparcia ZPB, jako organizacji reprezentującej na Białorusi polską mniejszość narodową. Władze RP oceniły, iż przeprowadzone w Wołkowysku wybory odbyły się z naruszeniem statutu organizacji oraz białoruskiego prawa. Ich przebieg uznano za niedemokratyczny ${ }^{5}$. $Z$ tego względu rządzący wówczas gabinet Marka Belki podjął decyzję o zaprzestaniu dotowania ZPB kierowanego przez Józefa Łucznika ${ }^{6}$. Partnerem przy przekazywaniu pomocy dla mniejszości polskiej

' Szerzej na temat politycznego zaangażowania ZPB zob. S. MiкoŁAJczak, Polacy na Białorusi w latach 1987-2008. Funkcjonowanie organizacji mniejszości polskiej w systemie politycznym, Poznań 2013, s. 141-142, 166-182, 204-223.

2 P. KościŃski, PAP, Związek będzie apolityczny, „Rzeczpospolita” 20 XI 2000, nr 270, s. A1, A8.

3 P. KościŃski, Zmiany w Związku Polaków na Białorusi, ,Rzeczpospolita” 14 III 2005, nr 61, s. A7.

${ }^{4}$ P. KościŃsKI, Zjazd pod dyktando Łukaszenki, „Rzeczpospolita” 29 VIII 2005, nr 201, s. 5.

${ }^{5}$ Komunikat MSZ z 6 IX 2005, Stanowisko Ministerstwa Spraw Zagranicznych wobec sytuacji Związku Polaków na Białorusi, http://www.msz.gov.p1/Stanowisko,Ministerstwa,Spraw,Zagraniczn ych,wobec,sytuacji,Zwiazku,Polakow,na,Bialorusi,317.html [dostęp: 24 II 2011] [dalej: Komunikat MSZ z 6 IX 2005].

6 M. Markowski, Pomoc za plecami białoruskich władz, „Gazeta Wyborcza” 29 VIII 2005, nr 200, s. 11; W. RaDZIWINOwICZ, Łukaszenko zabrat zwiazek, „Gazeta Wyborcza” 29 VIII 2005 , nr 200, s. 1 . 
stał się zarząd z Andżeliką Borys na czele, którą uznano za jedynego legalnie wyłonionego prezesa organizacji ${ }^{7}$. Białoruscy funkcjonariusze państwowi odpowiedzialni za sytuację, w jakiej znalazł się związek, jak też przedstawiciele polskiej mniejszości, którzy przyczynili się do zdelegalizowania uczciwie wyłonionego zarządu, zostali wpisani na listę osób niepożądanych w Polsce ${ }^{8}$.

Przyjęta przez rząd Marka Belki polityka wobec kryzysu w ZPB została zaaprobowana przez najważniejsze na polskiej scenie politycznej partie opozycyjne, tj. Platformę Obywatelską (PO) oraz Prawo i Sprawiedliwość (PiS). W środowisku postsolidarnościowym niczym nieuzasadnione unieważnienie VI Zjazdu Delegatów uznano za typowe dla państwa rządzonego w sposób autorytarny. Jedynego sposobu na zagwarantowanie związkowi swobody funkcjonowania upatrywano w przeorientowaniu systemu politycznego Białorusi na całkowicie demokratyczny ${ }^{9}$. W latach 2005-2007 zdominowane przez PiS gabinety, przy poparciu opozycyjnej PO, próbowały zainicjować transformację ustrojową w tym państwie poprzez wsparcie demokratycznej opozycji oraz izolowanie białoruskich władz.

Po zwycięstwie PO w wyborach parlamentarnych w Polsce jesienią 2007 r., nastąpiła istotna korekta prowadzonej dotąd polityki zagranicznej wobec Białorusi. Rząd Donalda Tuska zdecydował się bowiem na nawiązanie oficjalnych kontaktów z przedstawicielami białoruskiego rządu. Przyczyną zmiany stanowiska prezentowanego w środowisku PO stała się sytuacja międzynarodowa. W obliczu poważnych napięć w relacjach gospodarczych Białorusi z Rosją, od początku 2007 r. bezpośrednie kontakty z Mińskiem zaczęła nawiązywać Unia Europejska. Kreatorzy polskiej polityki zagranicznej w ociepleniu stosunków białorusko-unijnych dostrzegli szansę na zbliżenie swego wschodniego sąsiada do Zachodu, a tym samym zapewnienie jego niezależności od Rosji. Wykazując ambicję do przewodzenia wschodniej aktywności UE, reprezentanci PO uznali, iż utrzymując izolację białoruskich władz, Polska pozostawała na uboczu europejskiej polityki. Celem gabinetu Donalda Tuska stało się wpisanie Warszawy w rozpoczęty już dialog oraz zyskanie decydującego wpływu na jego kształt. W tej sytuacji konieczne stało się ocieplenie dwustronnych relacji. Zdecydowanie najpoważniejszą barierą w rozwoju kontaktów z Białorusią był utrzymujący się kryzys w ZPB. Zdominowany przez PO rząd stanął na stanowisku, iż problem ten jak najszybciej powinien zostać rozwiązany. Zadanie wypracowania odpowiedniej

7 Komunikat MSZ z 6 IX 2005.

${ }^{8}$ Kancelaria Sejmu, Biuletyn nr 4615/IV z posiedzenia Komisji Łączności z Polakami za Granicą oraz Komisji Spraw Zagranicznych w dn. 20 V 2005, wypowiedź Jakuba Wolskiego.

9 A. WŁodarCZYK, Polskie środowiska polityczne wobec konfliktu w stosunkach polsko-biatoruskich w 2005 roku, ,Studia Podlaskie” 20(2012), s. 250. 
strategii powierzono Ministerstwu Spraw Zagranicznych, na którego czele stanął Radosław Sikorski.

Celem niniejszego artykułu jest zaprezentowanie koncepcji rozwiązania sporu wokół ZPB, przyjętej przez polski rząd w 2008 r., oraz ukazanie jej ewolucji w latach 2009-2010. Cezurę początkową wyznacza rok 2008, kiedy w rządzie Donalda Tuska sformułowany został pierwszy projekt zakończenia kryzysu w polskiej organizacji. Datą końcową jest natomiast rok 2010, w którym zapadła decyzja o zakończeniu prób rozwiązania problemów polskiej mniejszości w drodze dialogu z białoruskimi władzami. Główne pytanie badawcze dotyczy tego, jakie miejsce zajmowało zażegnanie kryzysu w ZPB w priorytetach polityki zagranicznej prowadzonej wobec Białorusi przez rząd Donalda Tuska. W artykule posłużyłam się kilkoma rodzajami źródeł. Do najważniejszych należą stenogramy z posiedzeń Sej$\mathrm{mu}$, Senatu oraz komisji parlamentarnych, prasa jak też dokumenty wytworzone przez organy władzy wykonawczej. W celu wyjaśnienia omawianych zagadnień, w pracy przywołuję wydarzenia sprzed $2008 \mathrm{r}$. Z tego względu w przypisach znalazły się odniesienia do materiałów powstałych w okresie wykraczającym poza przyjęte ramy chronologiczne. W artykule przytaczam również wspomnienia pierwszego prezesa ZPB, Tadeusza Gawina, jak też kilka pozycji z literatury naukowej dotyczących polskiej mniejszości narodowej na Białorusi.

\section{WYPRACOWANIE PROGRAMU ZJEDNOCZENIOWEGO ORAZ PRÓBA JEGO REALIZACJI W 2008 R.}

W resorcie dyplomacji rozważane były różne scenariusze ustabilizowania sytuacji ZPB. Jeden z nich zakładał utrzymanie powstałego w 2005 r. stanu do czasu, gdy na Białorusi nastąpią zmiany ustrojowe ${ }^{10}$. Radosław Sikorski, oceniając działalność kierowanej przez Andżelikę Borys organizacji, zauważał, iż mimo panującego w tym państwie systemu autorytarnego, niezmiennie od 2005 r. wykazywała ona dużą aktywność na rzecz polskiej mniejszości. Funkcjonowanie w warunkach braku legalności nie pozostawało jednak bez wpływu na jej osiągnięcia. Odnotowywano na przykład spadek liczby dzieci uczących się języka polskiego, jak też trudności w organizowaniu imprez kulturalnych. W odczuciu ministra problemem

${ }^{10}$ Kancelaria Sejmu, Biuletyn nr 1339/VI z posiedzenia Komisji Łączności z Polakami za Granicą w dn. 15 X 2008 [dalej: Biuletyn nr 1339/VI], wypowiedź Andrzeja Kremera; Archiwum Rady Ministrów Kancelarii Prezesa Rady Ministrów [dalej: Archiwum Rady Ministrów], Sekretariat Prezesa Rady Ministrów Donalda Tuska, Rządowe programy współpracy z zagranicą 2009, t. II, sygn. $1535 / 1 / 2$, Notatka ministra, k. 4. 
było również przejmowanie związkowego majątku przez grupę Józefa Łucznika. Pozostające pod jej kontrolą mienie nie było bowiem efektywnie wykorzystywane na rzecz polskiej mniejszości ${ }^{11}$. W wydanym w 2009 r. Raporcie o sytuacji Polonii i Polaków za granica MSZ diagnozowało, iż w czternastu Domach Polskich znajdujących się pod zwierzchnictwem uznawanego przez Mińsk zarządu zamarła działalność społeczna, kulturalna i oświatowa ${ }^{12}$. Kierując się taką oceną, MSZ za rozwiązanie najkorzystniejsze dla Polaków na Białorusi potraktował doprowadzenie do zalegalizowania kierowanej przez A. Borys organizacji ${ }^{13}$.

Za idealną metodę zapewnienia związkowi swobody funkcjonowania, Radosław Sikorski uważał wycofanie się Mińska z przyjętej w 2005 r. polityki. Oznaczałoby to anulowanie decyzji Ministerstwa Sprawiedliwości o unieważnieniu VI Zjazdu ZPB, i tym samym uznanie prezesury Andżeliki Borys. Zawłaszczony przez J. Łucznika majątek wróciłby wówczas pod zarząd demokratycznie wyłonionych władz związku. R. Sikorski zdawał sobie jednak sprawę z nikłych szans na przyjęcie przez białoruskie władze takiego rozwiązania ${ }^{14}$. $Z$ tego względu w kierowanym przez niego resorcie za konieczne uznano poszukiwanie kompromisowego sposobu rozstrzygnięcia problemu ZPB. Podsekretarz stanu w MSZ Andrzej Kremer przekonywał, iż ,jakiejkolwiek metody by nie przyjęto, to ona musi zostać zaakceptowana przez władze Białorusi. W przeciwnym razie nie będzie możliwa legalizacja Związku Polaków na Białorusi"15. W tym celu za konieczne uznano na-

${ }^{11}$ Archiwum Rady Ministrów, Sekretariat Prezesa Rady Ministrów Donalda Tuska, Rządowe programy współpracy z zagranicą 2009, t. II, sygn. 1535/1/2, Notatka ministra, k. 3.

12 Raport o sytuacji Polonii i Polaków za granica 2009, red. K. Sawicki i zespół pracowników Departamentu Współpracy z Polonią MSZ, Warszawa 2009, s. 60. Po dokonaniu się rozłamu w ZPB w oddziałach regionalnych przeprowadzane były zebrania wyborcze do lokalnych organów kierowniczych. Pod wpływem zabiegów białoruskich władz większość oddziałów, wraz ze znajdującymi się na ich terenie domami polskimi została podporządkowana ZPB Józefa Łucznika. Zob. T. GAwIN, Polskie odrodzenie na Białorusi 1988-2005, Białystok 2010, s. 377-378; TENŻE, Zwiąek Polaków na Białorusi. Historia niszczenia niezależności 1988-2005, Białystok 2006, s. 247-248, 282-283.

${ }_{13}$ Kancelaria Sejmu, Biuletyn nr 1339/VI, wypowiedź Andrzeja Kremera; Archiwum Rady Ministrów, Sekretariat Prezesa Rady Ministrów Donalda Tuska, Rządowe programy współpracy z zagranicą 2009, t. II, sygn. 1535/1/2, Notatka ministra, k. 5; Kancelaria Sejmu, Biuletyn nr 1227/VI z posiedzenia Komisji Spraw Zagranicznych oraz Komisji Łączności z Polakami za Granicą w dn. 2 X 2008, wypowiedź Andrzeja Kremera.

${ }^{14}$ Archiwum Rady Ministrów, Sekretariat Prezesa Rady Ministrów Donalda Tuska, Rządowe programy współpracy z zagranicą 2009, t. II, sygn. 1535/1/2, Notatka ministra, k. 4; Kancelaria Sejmu, Biuletyn nr 3632/VI z posiedzenia Komisji Spraw Zagranicznych w dn. 7 IV 2010 [dalej: 3632/ VI], wypowiedź Radosława Sikorskiego.

${ }^{15}$ Kancelaria Sejmu, Biuletyn nr 1339/VI, wypowiedź Andrzeja Kremera. Zob. też Sprawozdanie stenograficzne z 35. posiedzenia Sejmu RP w dn. 13 II 2009, wypowiedź Radosława Sikorskiego. 
wiązanie z osobami rządzącymi Białorusią bezpośrednich kontaktów ${ }^{16}$. Cytowany powyżej wiceminister w październiku $2008 \mathrm{r}$. informował posłów, iż rząd ,[...] zmienił pewien tok myślenia, który występował przez ostatnie trzy lata, polegający na tym, że Polska nie toczy dialogu z władzami białoruskimi, dopóki Białoruś nie ureguluje sytuacji Związku Polaków na Białorusi. Zmieniono ten punkt widzenia na taki, który zakłada, że należy podjąć dialog z władzami białoruskimi, aby między innymi uregulować sytuację Związku Polaków na Białorusi" ${ }^{17}$.

W 2008 r. przedstawiciele MSZ podjęli poufne rozmowy z białoruskimi dyplomatami na temat położenia polskiej mniejszości. $\mathrm{W}$ ich wyniku powołany został dwustronny zespół roboczy, który zajął się wypracowaniem sposobu zakończenia konfliktu wokół ZPB. W trakcie rokowań strona białoruska przeforsowała rozwiązanie zakładające połączenie obu związków ${ }^{18}$. Rozmowy zjednoczeniowe przeprowadzić miała grupa społeczna, złożona z czterech przedstawicieli związku kierowanego przez Józefa Łucznika oraz czterech reprezentantów organizacji Andżeliki Borys $^{19}$. Efektem negocjacji powinno być ustalenie terminu Zjazdu ZPB. Polski resort dyplomacji podjął próbę przekonania wspieranego przez siebie zarządu do przyjęcia tej oferty. 9 września 2008 r. A. Borys oraz jej najbliżsi współpracownicy zostali zaproszeni do $\mathrm{MSZ}^{20}$. Podczas spotkania z Andrzejem Kremerem ustalono, iż decyzję o ewentualnych rozmowach podejmie Rada Naczelna ${ }^{21}$. Według doniesień polskiej prasy, wiceminister przekazał wówczas liderom ZPB żądanie białoruskich władz wykluczenia z grupy negocjacyjnej Andżeliki Borys ${ }^{22}$. Informacja ta stała się przyczyną spekulacji medialnych na temat rzekomej próby nakłonienia prezes związku do rezygnacji ze stanowiska. Polscy dyplomaci proponować mieli,

${ }^{16}$ Kancelaria Sejmu, Biuletyn nr 2747/VI z posiedzenia Komisji Spraw Zagranicznych w dn. 23 IX 2009, wypowiedź Radosława Sikorskiego; Kancelaria Sejmu, Biuletyn nr 3329/VI z posiedzenia Komisji Łączności z Polakami za Granicą w dn. 22 I 2010 [dalej: Biuletyn nr 3329/VI], wypowiedź Jana Borkowskiego; Sprawozdanie stenograficzne z 61. posiedzenia Sejmu RP w dn. 18 II 2010, wypowiedź Jana Borkowskiego; Sprawozdanie stenograficzne z 35. posiedzenia Sejmu RP w dn. 13 II 2009, wypowiedź Radosława Sikorskiego.

${ }^{17}$ Kancelaria Sejmu, Biuletyn nr 1339/VI, wypowiedź Andrzeja Kremera.

18 M. Majewski, P. ReszKa, Jak polskie MSZ chciało kosztem Andżeliki Borys ucywilizować Eukaszenke, ,Rzeczpospolita” 6 X 2008, nr 234, s. 8. Na czele polskich negocjatorów stanął wicedyrektor departamentu w MSZ Wojciech Tyciński.

${ }^{19}$ P. KoścIŃsKI, A jednak MSZ chciat poświęcić pania Borys, „Rzeczpospolita” 4-5 X 2008, nr 233, s. A2.

${ }^{20}$ M. Majewski, P. ReszKa, Waterloo polskiej dyplomacji, „Dziennik Polska Europa Świat” 4-5 X 2008, nr 233, s. 1; Kancelaria Sejmu, Biuletyn nr 1339/VI, wypowiedź Andrzeja Kremera.

${ }^{21}$ M. Majewski, P. ReszKa, Jak polskie MSZ, s. 9; Kancelaria Sejmu, Biuletyn nr 1339/VI, wypowiedź Andrzeja Kremera.

${ }^{22}$ M. MajewsKi, P. ResZKa, Jak polskie MSZ, s. 8. 
aby kandydatką na przewodniczącą zjednoczonej organizacji została wierna demokratycznemu zarządowi Alina Jaroszewicz z Brześcia ${ }^{23}$. Andrzej Kremer oficjalnie zdementował te informacje $\mathrm{e}^{24}$.

Na posiedzeniu 20 września 2008 r. Rada Naczelna ZPB odmówiła zgody na negocjacje z grupą Józefa Łucznika. Rekomendowała jednocześnie kierownictwu związku podjęcie rozmów bezpośrednio z białoruskimi władzami ${ }^{25}$. W tej sytuacji w MSZ zapadła decyzja o zaniechaniu dalszych działań na rzecz pogodzenia zwaśnionych stron ${ }^{26}$. W odczuciu przedstawicieli resortu sposób rozwiązania kryzysu w polskiej organizacji musiał bowiem zostać zaakceptowany nie tylko przez białoruskie władze, ale też wspieranych przez Warszawę działaczy ${ }^{27}$.

\section{ZWIĄZEK POLAKÓW NA BIAŁORUSI W STOSUNKACH POLSKO-BIALORUSKICH W 2009 R.}

W kolejnych miesiącach polska dyplomacja aktywnie wspomagała starania Andżeliki Borys o rozpoczęcie dialogu z białoruskim rządem ${ }^{28}$. Władze państwowe nie zgodziły się jednak na rozmowy z nieuznawanym przez siebie kierowni-

${ }^{23}$ P. KoścIŃsKi, Borys za lepsze stosunki?, „Rzeczpospolita” 19 IX 2008, nr 220, s. A3.

${ }^{24}$ Kancelaria Sejmu, Biuletyn nr 1339/VI, wypowiedź Andrzeja Kremera; W. RADZIWINowicz, Zamieszanie wokół Związu Polaków na Białorusi, „Gazeta Wyborcza” 20-21 IX 2008, nr 221, s. 10. W wyniku enuncjacji prasowych najwyższe władze RP postanowiły zadeklarować zdecydowane poparcie dla Andżeliki Borys. 23 września 2008 r. spotkał się z nią Donald Tusk. Premier oświadczył wówczas, iż Polska uznaje wyłącznie kierowaną przez nią organizację. Zob. P. KoścıŃski, Tusk uznaje tylko Borys, „Rzeczpospolita” 24 IX 2008, nr 224, s. A6. Dnia 8 października 2008 r. prezes ZPB przyjął natomiast prezydent Lech Kaczyński. Zob. P. KoścIŃsKI, Lech Kaczyński wspiera Borys, „Rzeczpospolita” 9 X 2008, nr 237, s. A5.

${ }^{25}$ W. Radziwinowicz, Ludzie Andżeliki Borys nie ufaja Warszawie?, „Gazeta Wyborcza” 22 IX 2008, nr 222, s. 12.

${ }^{26}$ P. KościŃsKi, PAP, AFP, Gest wobec Mińska, „Rzeczpospolita” 10 X 2008, nr 238, s. A12; Archiwum Rady Ministrów, Sekretariat Prezesa Rady Ministrów Donalda Tuska, Rządowe programy współpracy z zagranicą 2009, t. II, sygn. 1535/1/2, Notatka ministra, k. 5.

${ }^{27}$ Kancelaria Sejmu, Biuletyn nr 1339/VI, wypowiedź Andrzeja Kremera; W. RADZIwINowicz, Zamieszanie wokół Zwiąku Polaków na Białorusi, „Gazeta Wyborcza” 20-21 IX 2008, nr 221, s. 10; Kancelaria Sejmu, Biuletyn nr 3406/VI z posiedzenia Komisji Łączności z Polakami za Granicą oraz Komisji Spraw Zagranicznych w dn. 11 II 2010 [dalej: Biuletyn nr 3406/VI], wypowiedź Andrzeja Kremera.

${ }^{28}$ Formalnie z inicjatywą nawiązania kontaktu wystąpiła Andżelika Borys, wysyłając list do władz Białorusi. Zob. Archiwum Rady Ministrów, Sekretariat Prezesa Rady Ministrów Donalda Tuska, Rządowe programy współpracy z zagranicą 2009, t. II, sygn. 1535/1/2, Notatka ministra, k. 3 . 
ctwem. 19 stycznia 2009 r. A. Borys przyjął jedynie szef Wydziału ds. Wyznań i Narodowości obwodu grodzieńskiego ${ }^{29}$. W ocenie Radosława Sikorskiego było to spotkanie na niskim szczeblu, które w dodatku nie przyniosło pożądanych efektów. Andżelika Borys oczekiwała bowiem legalizacji swego związku, deklarując jednocześnie gotowość włączenia do niego osób z konkurencyjnej organizacji. Wykluczała jednak możliwość przyjęcia najbardziej skompromitowanych współpracowników Józefa Łucznika ${ }^{30}$. Białoruskie władze proponowały natomiast przystąpienie skupionych wokół niej działaczy do legalnie funkcjonującego związku³

Polski rząd, podejmując dyplomatyczne zabiegi na rzecz zalegalizowania stowarzyszenia Andżeliki Borys, oczekiwał jednocześnie, iż do tego czasu białoruskie władze umożliwią mu swobodne funkcjonowanie. Od warunków stwarzanych tej organizacji, Warszawa oficjalnie uzależniała rozwój dwustronnych relacji ${ }^{32}$. Na początku 2009 r. za wyznacznik intencji Mińska polskie MSZ uznało jego postawę wobec zaplanowanego na 14-15 marca w Baranowiczach Zjazdu ZPB. W związku z kończącą się kadencją wyłonionego przed czterema laty zarządu, w jego trakcie miały zostać przeprowadzone wybory prezesa organizacji. Gdyby Zjazd nie odbył się w statutowym terminie, Polska stanęłaby przed problemem legalizmu uznawanej przez siebie organizacji. Kilka tygodni przed wyznaczoną datą pojawiały się natomiast informacje o próbach zastraszenia działaczy ZPB, jak też naciskach na kierownictwo Domu Polskiego w Baranowiczach. Wydarzenia te w Warszawie zinterpretowano jako przejawy negatywnego nastawienia władz Białorusi wobec decyzji Andżeliki Borys o przeprowadzeniu wyboru zarządu bez konsultacji ze środowiskiem Józefa Łucznika ${ }^{33}$.

W sytuacji zablokowania Zjazdu ZPB polski rząd zapowiadał wycofanie poparcia dla białoruskich interesów na forum UE. W Brukseli ważyły się wówczas losy sankcji wizowych nałożonych na przedstawicieli władz Białorusi. Rozważana była również możliwość włączenia tego państwa do Partnerstwa Wschodniego ${ }^{34}$.

${ }^{29}$ T. SeRWeTnyK, PAP, Pani Borys bliżej dialogu z władza??, „Rzeczpospolita” 26 I 2009, nr 21, s. A13.

${ }^{30}$ Archiwum Rady Ministrów, Sekretariat Prezesa Rady Ministrów Donalda Tuska, Rządowe programy współpracy z zagranicą 2009, t. II, sygn. 1535/1/2, Notatka ministra, k. 3.

31 Tamże, k. 3-4.

${ }^{32}$ D. Tusk, Nowe exposé, rozmowę przeprowadził J. Baczyński, J. Paradowska, „Polityka” 4 X 2008, nr 40, s. 16.

33 Archiwum Rady Ministrów, Sekretariat Prezesa Rady Ministrów Donalda Tuska, Rządowe programy współpracy z zagranicą 2009, t. II, sygn. 1535/1/2, Notatka ministra, k. 3-4.

${ }^{34}$ Tamże, k. 3; A. SŁoJEwSKa, Unijne chmury nad Łukaszenka, ,Rzeczpospolita” 14-15 III 2009, nr 62, s. A9; J. Bielecki, Polacy nie wystraszyli się Łukaszenki, „Dziennik Polska Europa Świat” 16 III 2009, nr 63, s. 9. 
W przypadku negatywnego rozwoju sytuacji wokół organizacji Andżeliki Borys, Warszawa mogła podjąć starania o rozstrzygnięcie tych kwestii na niekorzyść Mińska. Faktycznie jednak polskie władze nie były zainteresowane zahamowaniem zbliżenia unijno-białoruskiego, jak też przerwaniem zapoczątkowanego pod koniec 2007 r. dwustronnego dialogu. Świadczył o tym plan, jaki powstał w MSZ na wypadek nieprzeprowadzenia Zjazdu, oraz odmowy legalizacji wspieranego przez Warszawę związku. Zakładał on podjęcie rozmów z Andżeliką Borys oraz jej współpracownikami na temat zarejestrowania ich stowarzyszenia pod inną nazwą ${ }^{35}$. Rezygnacja z szyldu Związku Polaków na Białorusi wiązać się miała z utratą majątku, który należał do instytucji o tej nazwie. Radosław Sikorski rozwiązanie to uznał za korzystne dla środowiska mniejszości oraz możliwe do przyjęcia przez władze Białorusi. Ich niechęć do uznania ZPB kierowanego przez A. Borys szef resortu dyplomacji tłumaczył obawą Aleksandra Łukaszenki przed poniesieniem wizerunkowej porażki, a nie brakiem zainteresowania rozwojem relacji z Polską. Według ministra stworzenie pluralizmu polskich organizacji umożliwiłoby kontynuację dwustronnego dialogu ${ }^{36}$. W jego ocenie alternatywą byłyby kolejne lata impasu w sprawie ZPB, niosące negatywne skutki „dla polskości na Białorusi [...] stosunków polsko-białoruskich, a także polskiej polityki zagranicznej na Wschodzie" ${ }^{37}$. Plan ten pokazywał, iż polskie władze, mimo oficjalnych deklaracji, w rzeczywistości były gotowe pójść na ustępstwa w kwestii ZPB w imię utrzymania dialogu ze wschodnim sąsiadem.

Ostatecznie, Zjazd ZPB został przeprowadzony w zaplanowanym terminie w Grodnie. W jego trakcie na prezesa ponownie wybrano Andżelikę Borys ${ }^{38}$. W tej sytuacji Polska podczas posiedzenia Rady Unii Europejskiej poparła stanowisko zakładające zawieszenie wykonania unijnych sankcji wizowych nałożonych na białoruskich oficjeli ${ }^{39}$. Warszawa opowiedziała się również za przyłączeniem są-

${ }^{35}$ Archiwum Rady Ministrów, Sekretariat Prezesa Rady Ministrów Donalda Tuska, Rządowe programy współpracy z zagranicą 2009, t. II, sygn. 1535/1/2, Notatka ministra, k. 5; Kancelaria Sejmu, Biuletyn nr 3329/VI, wypowiedź Jana Borkowskiego.

${ }^{36}$ Archiwum Rady Ministrów, Sekretariat Prezesa Rady Ministrów Donalda Tuska, Rządowe programy współpracy z zagranicą 2009, t. II, sygn. 1535/1/2, Notatka ministra, k. 4-5.

37 Tamże, k. 5.

38 J. Bielecki, Polacy nie wystraszyli się Eukaszenki, s. 9; W. Radziwinowicz, Białoruscy Polacy nielegalnie, ale działaja, „Gazeta Wyborcza” 16 III 2009, nr 63, s. 10; PAP, ZS, Andżelika Borys ponownie prezesem, „Trybuna” 16 III 2009, nr 63, s. 7; P. KościŃski, Polacy pod parasolem Unii, „Rzeczpospolita” 16 III 2009, nr 63, s. A10.

39 A. SŁoJewsKa, Unijna marchewka dla Mińska, „Rzeczpospolita” 17 III 2009, nr 64, s. A9; D. PszczóŁKowsKa, Europa nagradza Łukaszenke, „Gazeta Wyborcza” 17 III 2009, nr 64, s. 10; agaw, UE przedluża zawieszenie sankcji wobec Białorusi, „Tydzień na Wschodzie” 18 III 2009, nr 11, s. 9-10. 
siedniego państwa do Partnerstwa Wschodniego ${ }^{40}$. Niezakłócony przebieg Zjazdu organizacji Andżeliki Borys, w szeregach rządu jak też w środowisku PO, uznano za sukces polityki poszukiwania rozstrzygnięcia kwestii ZPB w drodze kompro$\mathrm{misu}^{41}$. W ocenie wiceministra spraw zagranicznych Jana Borkowskiego od tego czasu w stosunkach polsko-białoruskich zapanowała „krucha równowaga wokół Związku Polaków na Białorusi" "2 . W kolejnych miesiącach polscy dyplomaci kontynuowali zabiegi na rzecz osiągnięcia ostatecznego porozumienia. W 2009 r. odbyło się spotkanie polsko-białoruskiej grupy roboczej ds. problemów mniejszości narodowych. Temat Polaków na Białorusi omawiany był również podczas spotkań szefa Kancelarii Prezesa Rady Ministrów Tomasza Arabskiego z szefem Administracji Prezydenta Białorusi Uładzimirem Makiejem ${ }^{43}$. Według informacji przekazanych przez przedstawiciela MSZ, sposobem na skłonienie Mińska do przyjęcia polskich postulatów w kwestii ZPB było wiązanie tego tematu $\mathrm{z}$ innymi wymiarami wzajemnych relacji, jak zwiększająca się współpraca gospodarcza, podjęty dialog polityczny, czy też udział Białorusi w Partnerstwie Wschodnim ${ }^{44}$. Proces poszukiwania kompromisu zachwiany został na początku $2010 \mathrm{r}$. w związku z wydarzeniami wokół Domu Polskiego w Iwieńcu.

\section{WYDARZENIA WOKÓŁ DOMU POLSKIEGO W IWIEŃCU I ICH WPŁYW NA POLSKĄ POLITYKĘ ZAGRANICZNĄ WOBEC BIAŁORUSI}

Iwieniecki oddział ZPB od 2005 r. podlegał zwierzchnictwu Andżeliki Borys $^{45}$. W 2009 r. do Polski zaczęły docierać informacje o realnej groźbie utraty funkcjonującego tam Domu Polskiego na rzecz konkurencyjnego zarządu. Podjęte

40 J. Bielecki, Polacy nie wystraszyli się Łukaszenki, s. 9. Utrzymanie poparcia dla udziału Białorusi w programie uzależniano jednak m.in. od dalszej polityki białoruskich władz wobec polskiej mniejszości. Zob. J. BIELECKI, Polacy nie wystraszyli się Eukaszenki, „Dziennik Polska Europa Świat” 16 III 2009, nr 63, s. 9. Zob. też Sprawozdanie stenograficzne z 39. posiedzenia Sejmu RP w dn. 2 IV 2009, wypowiedź Jana Borkowskiego.

${ }^{41}$ Kancelaria Sejmu, Biuletyn nr 3329/VI, wypowiedź Jana Borkowskiego; A. SŁoJEwSKA, Unijna marchewka dla Mińska, s. A9.

${ }^{42}$ Kancelaria Sejmu, Biuletyn nr 3329/VI, wypowiedź Jana Borkowskiego; Sprawozdanie stenograficzne z 61. posiedzenia Sejmu RP w dn. 18 II 2010, wypowiedź Jana Borkowskiego.

43 A. Poczobut, Człowiek Łukaszenki w Polsce, „Gazeta Wyborcza” 3 XI 2009, nr 258, s. 4; Kancelaria Sejmu, kadencja VII, Odpowiedź podsekretarz stanu w MSZ z upoważnienia prezesa Rady Ministrów na interpelację nr 9994 w sprawie realizacji zadań przez Departament Współpracy z Polonią MSZ.

${ }^{44}$ Kancelaria Sejmu, Biuletyn nr 3329/VI, wypowiedź Jana Borkowskiego.

${ }^{45}$ Raport o sytuacji Polonii i Polaków za granica 2009, s. 60. 
działania dyplomatyczne nie zapobiegły eskalacji napięcia. Na początku $2010 \mathrm{r}$. wobec szefowej oddziału, a jednocześnie kierowniczki Domu Polskiego w Iwieńcu Teresy Sobol, zostało wszczęte postępowanie karne za bezprawne przyjęcie w 2004 r. zapomogi od centrali związku ${ }^{46}$. Uznawany przez Mińsk zarząd, na którego czele od sierpnia 2009 r. stał Stanisław Siemaszko ${ }^{47}$, wykluczył tę wieloletnią aktywistkę z ZPB. Zarzucono jej łamanie statutu oraz działalność na szkodę organizacji. Następnie, na 21 stycznia 2010 r. zarządzono wybory nowego kierownictwa oddziału ${ }^{48}$.

W zaistniałej sytuacji polski MSZ za konieczne uznał podjęcie środków dyplomatycznej perswazji i nacisku ${ }^{49}$. Mając świadomość rosnącego napięcia, 14 stycznia 2010 r. przebywający na Białorusi Andrzej Kremer, podczas rozmowy z wiceministrem spraw zagranicznych Walerijem Woronieckim, ostrzegał, iż nieprzyjazne działania wobec Domu Polskiego w Iwieńcu uniemożliwią budowę normalnych relacji międzypaństwowych ${ }^{50} .20$ stycznia 2010 r. ambasador Henryk Litwin poinformował naczelnika służby zagranicznej Administracji Prezydenta Białorusi o negatywnym wpływie zaistniałych wydarzeń na stosunki polsko-białoruskie. Następnego dnia dyrektor Departamentu Wschodniego MSZ przestrzegał ambasadora Białorusi w Polsce przed działaniami eskalującymi napięcia. W dniu zaplanowanych wyborów, w Domu Polskim w Iwieńcu pojawili się przedstawiciele Wydziału Konsularnego Ambasady RP w Mińsku ${ }^{51}$.

Zabiegi polskich dyplomatów nie przyniosły jednak oczekiwanych efektów. 21 stycznia 2010 r. kilkudziesięciu członków nieuznawanego w Mińsku ZPB, próbując dostać się do Iwieńca, trafiło do aresztu ${ }^{52}$. Mimo to działaczom wiernym

${ }^{46}$ WK, PAP, Szykany za zapomoge, „Nasz Dziennik” 7 I 2010, nr 5, s. 9.

47 Stanisław Siemaszko został wybrany na prezesa uznawanego przez Mińsk ZPB podczas Zjazdu 12 września 2009 r. Zob. W. WASILEwski, Reżimowy Związek Polaków na Białorusi ma nowego szefa, „Gazeta Wyborcza” 14 IX 2009, nr 215.

${ }^{48}$ M. Zygmunt, Białorusini tępią ludzi Borys, „Nasz Dziennik” 21 I 2010, nr 17, s. 4.

${ }^{49}$ Kancelaria Sejmu, Biuletyn nr 3329/VI, wypowiedź Jana Borkowskiego.

${ }^{50}$ Sprawozdanie stenograficzne z 62. posiedzenia Sejmu RP w dn. 4 III 2010, wypowiedź Jana Borkowskiego; Kancelaria Sejmu, Biuletyn nr 3303/VI z posiedzenia Komisji Łączności z Polakami za Granicą w dn. 21 I 2010 [dalej: Biuletyn nr 3303/VI], wypowiedź Macieja Szymańskiego.

${ }^{51}$ Kancelaria Sejmu, Biuletyn nr 3329/VI, wypowiedź Jana Borkowskiego; Kancelaria Sejmu, Biuletyn nr 3303/VI, wypowiedź Macieja Szymańskiego. Obecność polskich dyplomatów w Domu Polskim w Iwieńcu spotkała się ze sprzeciwem białoruskiego MSZ. W nocie przekazanej polskiemu ambasadorowi oskarżano niektórych pracowników Ambasady RP o postawę niezgodną z międzynarodowymi regulacjami prawnymi normującymi działalność dyplomatów. Zob. A. SŁoJEwsKA, P. KośCIŃsKI, Mińsk stawia warunki UE, „Rzeczpospolita” 28 I 2010, nr 23, s. A13; J. BIELECKI, Odwilż z Białorusia pod znakiem zapytania, „Dziennik Gazeta Prawna” 28 I 2010, nr 19, s. A5.

${ }_{52}$ M. Ziarnik, KGB poluje na Polaków, „Nasz Dziennik” 22 I 2010, nr 18, s. 2. 
demokratycznie wybranym władzom udało się przejąć kontrolę nad zebraniem wyborczym. W jego trakcie zadecydowano o pozostawieniu Teresy Sobol na piastowanym stanowisku ${ }^{53}$. W tej sytuacji Stanisław Siemaszko przeprowadził alternatywne wybory, w których uczestniczyła publiczność zebrana na koncercie białoruskiego zespołu Biesiada. Na prezesa iwienieckiego oddziału wybrany został dotychczasowy kierownik miejscowego domu kultury, Stanisław Buraczewski ${ }^{54}$. W reakcji na to wydarzenie działacze lojalni wobec Andżeliki Borys odmówili opuszczenia Domu Polskiego w Iwieńcu ${ }^{55} .8$ lutego 2010 r. budynek został zajęty przez milicję oraz przekazany Stanisławowi Buraczewskiemu. Tym samym siedziba iwienieckiego oddziału ZPB trafiła pod kontrolę funkcjonującego legalnie zarządu $^{56}$. Kwestię własności Domu Polskiego 15 lutego 2010 r. rozpatrzyć miał sąd w Wołożynie.

Wydarzenia te spowodowały stanowczy protest polskich władz. Wyrazem zaistniałego w stosunkach polsko-białoruskich napięcia było wezwanie na kilkudniowe konsultacje do kraju ambasadora Henryka Litwina ${ }^{57}$. Ponadto do MSZ w Warszawie wezwany został ambasador Republiki Białoruś Wiktar Gajsionek. Przyjmujący go Andrzej Kremer wyraził sprzeciw wobec akcji milicji oraz brutalnemu wyprowadzeniu z Domu Polskiego w Iwieńcu obecnych w nim osób. Wiceminister przestrzegał również przed dalszymi działaniami represyjnymi wobec ZPB. Wiktar Gajsionek wydarzenia w Iwieńcu uznał za wewnętrzną sprawę Białorusi ${ }^{58}$.

Zabiegi dyplomatyczne nie zahamowały kolejnych represji wobec członków nieuznawanego w Mińsku ZPB. W wyroku z 17 lutego sąd uznał Dom Polski w Iwieńcu za własność związku kierowanego przez Stanisława Siemaszkę ${ }^{59} .15$ lu-

53 A. Pisalnik, Jak obroniono Dom Polski, „Rzeczpospolita” 22 I 2010, nr 18, s. A12. Działacze ZPB nie wpuścili na zebranie Stanisława Siemaszko, który próbował dostać się do budynku w towarzystwie telewizyjnych kamer. Zob. R. Imielski, Białoruś nęka Polaków, „Gazeta Wyborcza” 22 I 2010, nr 18, s. 10.

54 W. Kobryń, Siemaszko stawia ultimatum Sobol, „Nasz Dziennik” 4 II 2010, nr 29, s. 8.

55 A. PisalniK, Ciag dalszy walki o Iwieniec, „Rzeczpospolita” 4 II 2010, nr 29, s. A10.

${ }^{56}$ A. Pisalnik, Zajazd na Dom Polski, „Rzeczpospolita” 9 II 2010, nr 33, s. A11; M. Ziarnik, Wyrzucili Polaków sita, „Nasz Dziennik” 9 II 2010, nr 33, s. 1, 2; J. PAwlicki, Dom Polski w Iwieńcu przejęty przez Mińsk, „Gazeta Wyborcza” 9 II 2010, nr 33, s. 11.

${ }^{57}$ Kancelaria Sejmu, Biuletyn nr 3406/VI, wypowiedź Macieja Szymańskiego; J. Pawlicki, Dom Polski w Iwieńcu przejęty przez Mińsk, s. 11. Ambasador RP wrócił do Mińska 11 lutego $2010 \mathrm{r}$. Zob. A. Pisalnik, K. Zuchowicz, Białoruski minister w Warszawie, „Rzeczpospolita” 12 II 2010 , nr 36, s. A12.

${ }^{58}$ Kancelaria Sejmu, Biuletyn nr 3406/VI, wypowiedź Macieja Szymańskiego; J. PAwLICKI, Dom Polski w Iwieńcu przejęty przez Mińsk, s. 11.

${ }^{59}$ A. PisalniK, Lapanka na polskich działaczy, „Rzeczpospolita” 16 II 2010, nr 39, s, A11; TENŻE, Dom Polski dla Polaków Łukaszenki, „Rzeczpospolita” 18 II 2010, nr 41, s. 1; A. PisAlniK, P. Koś- 
tego, tj. w dniu rozprawy, kilkudziesięciu planujących dostać się do Wołożyna działaczy, w tym Andżelika Borys, trafiło do aresztu ${ }^{60}$. Po kilku godzinach większość osób została wypuszczona na wolność. Nałożono na nich jednak wysokie kary finansowe za udział w nielegalnej demonstracji, która odbyła się tydzień wcześniej w Grodnie z okazji 70. rocznicy pierwszych wywózek Polaków na Syberię. Trzech działaczy ZPB zostało skazanych na pięć dni aresztu ${ }^{61}$.

Wydarzeniom wokół iwienieckiego oddziału ZPB towarzyszyło jeszcze jedno działanie represyjne wobec nieuznawanej przez Mińsk organizacji. Na początku lutego Sąd Gospodarczy w Grodnie nałożył wysoką grzywnę na kierowaną przez A. Borys spółkę Polonika, za pomocą której finansowana była działalność wspieranego przez Warszawę związku. Mandat stanowił karę za przyjmowanie środków pieniężnych od Stowarzyszenia Wspólnota Polska. Grzywna przesądziła o likwidacji Poloniki, gdyż firma nie miała możliwości zapłacenia wymaganej sumy ${ }^{62}$.

Polskie władze na represje wobec wspieranej przez siebie organizacji zareagowały w sposób umiarkowany. Za skuteczną metodę zahamowania wrogich działań, oprócz nacisków dyplomatycznych, uznano sankcje wizowe ${ }^{63}$. Do obowiązującego wykazu kilkunastu obywateli Białorusi posiadających zakaz wjazdu do Polski ${ }^{64}$,

CIŃSKI, Dom Polski zabrany, „Rzeczpospolita” 18 II 2010, nr 41, s. A10; W. KoBRYŃ, Sąd zabrał Dom Polski w Iwieńcu, „Nasz Dziennik” 18 II 2010, nr 41, s. 6; W. Radziwinowicz, Rozprawa z Polakami, „Gazeta Wyborcza” 18 II 2010, nr 41, s. 1. Wyrok sądu I instancji został utrzymany przez Sąd Obwodowy w Mińsku. Zob. TOBI, Dom Polski nie dla Andżeliki Borys, „Gazeta Wyborcza” 12 III 2010, nr 60, s. 10; A. PISALnIK, Sąd w Mińsku za konfiskata Iwieńca, „Rzeczpospolita” 12 III 2010 nr 60, s. A11; ŁS, PAP, Dom Polski nie dla Polaków, „Nasz Dziennik” 12 III 2010, nr 60, s. 9.

${ }^{60}$ Ł. StAnOżĘCKI, Lapanka na Polaków, „Nasz Dziennik” 16 II 2010, nr 39, s. 1.

${ }^{61}$ A. Pisalnik, Białoruś uderza w Polaków, „Rzeczpospolita” 16 II 2010, nr 39, s. 1; A. PisalNIK, Lapanka na polskich działaczy, s. A11.

62 A. PisalniK, Zajazd na Dom Polski, s. A11; WJ, Białoruś zamyka polska szkołę, „Gazeta Wyborcza” 6-7 II 2010, nr 31, s. 9; dyn, Mińsk wzmaga represje wobec ZPB Andżeliki Borys, „Tydzień na Wschodzie" 10 II 2010, nr 6, s. 10. Dnia 16 marca 2010 r. mandat został utrzymany przez Najwyższy Sąd Gospodarczy w Mińsku. Spółka nie miała możliwości opłacenia grzywny. Na poczet niezapłaconej kary wiosną 2010 r. komornicy zajęli mienie użytkowane przez spółkę, mimo iż jego część stanowiła własność Konsulatu Generalnego RP w Grodnie. Zob. MBZ, PAP, Ambasada się odwoła, „Nasz Dziennik” 17 III 2010, nr 64, s. 8; A. PISALnIK, Komornicy w firmie Andżeliki Borys, „Rzeczpospolita” 5 V 2010, nr 103, s. A11.

${ }^{63}$ K. Zuchowicz, A. Pisalnik, Białoruś ustyszała warunki, „Rzeczpospolita” 13-14 II 2010, nr 37, s. A8; Sprawozdanie stenograficzne z 61. posiedzenia Sejmu RP w dn. 18 II 2010, wypowiedź Jana Borkowskiego.

${ }^{64}$ Przed wydarzeniami wokół oddziału ZPB w Iwieńcu takimi restrykcjami objętych było kilkanaście osób, oskarżanych o niszczenie struktur ZPB oraz prowadzenie antypolskiej kampanii. MSZ stało na stanowisku, iż zakaz wjazdu do kraju powinien dotyczyć jak najmniejszej grupy osób polskiego pochodzenia. Nie rezygnowano jednak z tej metody, gdyż jak tłumaczył przedstawiciel MSZ 
wprowadzone zostały dodatkowe nazwiska ${ }^{65}$. Restrykcje wizowe nałożono na członków nieuznawanego przez Warszawę zarządu ZPB oraz urzędników oskarżanych o niszczenie struktur organizacji polskiej mniejszości ${ }^{66}$. Ponadto, przedstawiciele resortu dyplomacji sytuację, w jakiej znaleźli się Polacy na Białorusi, przedstawili na forum międzynarodowym. Radosław Sikorski podjął na ten temat rozmowy ze stojącym wówczas na czele OBWE ministrem spraw zagranicznych Kazachstanu. Z zaistniałymi na początku 2010 r. wydarzeniami zapoznany został również wysoki komisarz tej organizacji do spraw praw człowieka. Wyjaśniając sens zainteresowania OBWE kwestią polskiej mniejszości, przedstawiciele MSZ przypominali, iż była to jedyna organizacja narzucająca określone wymogi w kwestii ochrony praw człowieka, do której należała Białoruśs ${ }^{67}$.

Polski punkt widzenia na wydarzenia wokół Domu Polskiego w Iwieńcu prezentowany był również w ramach UE. Radosław Sikorski o zaistniałej sytuacji poinformował poszczególne państwa, a także wysokiego przedstawiciela ds. wspólnej polityki zagranicznej i bezpieczeństwa UE Catherine Ashton ${ }^{68}$. Polscy dyplomaci nie podjęli natomiast na forum unijnym zabiegów na rzecz realnego ukarania białoruskich władz. Na wniosek R. Sikorskiego C. Ashton wydała wprawdzie oświadczenie informujące Mińsk, iż niedawne wydarzenia wokół ZPB będą miały negatywne konsekwencje dla procesu wzmacniania unijno-białoruskich relacji ${ }^{69}$. W rzeczywistości jednak proces otwierania się Wspólnoty na Białoruś nie

Maciej Szymański: „obawa przed wpisaniem na listę hamuje bardzo skrajne postawy”. Zob. Kancelaria Sejmu, Biuletyn nr 3303/VI, wypowiedź Macieja Szymańskiego; Kancelaria Sejmu, Biuletyn nr 1074/VI z posiedzenia Komisji Łączności z Polakami za Granicą w dn. 3 IX 2008, wypowiedź Wojciecha Tycińskiego.

${ }^{65}$ Sprawozdanie stenograficzne z 61. posiedzenia Sejmu RP w dn. 18 II 2010, wypowiedź Jana Borkowskiego; Sprawozdanie stenograficzne z 62. posiedzenia Sejmu RP w dn. 4 III 2010, wypowiedź Jana Borkowskiego; A. GraBeK, Białoruś aresztuje, w Polsce wrze, Unia się przyglada, „Dziennik Gazeta Prawna” 16 II 2010, nr 32, s. A3.

${ }^{66}$ W. Radziwinowicz, P. Wroński, Łukaszenka ściga Polaków, „Gazeta Wyborcza” 16 III 2010, nr 39, s. 1; W. LoREnz, Białoruś uderza w Polaków, „Rzeczpospolita” 16 II 2010, nr 39, s. 1.

${ }^{67}$ Kancelaria Sejmu, Biuletyn nr 3406/VI, wypowiedź Macieja Szymańskiego i Jana Borkowskiego; Sprawozdanie stenograficzne z 61. posiedzenia Sejmu RP w dn. 18 II 2010, wypowiedź Jana Borkowskiego.

${ }^{68}$ Kancelaria Sejmu, Biuletyn nr 3406/VI, wypowiedź Macieja Szymańskiego; P. WroŃsKI, MSZ ostrzega Mińsk, „Gazeta Wyborcza” 16 II 2010, nr 39, s. 11; P. KościńsKi, PAP, MSZ ostrzej wobec Białorusi. Opozycja: za słabo, „Rzeczpospolita” 16 II 2010, nr 39, s. A11; A. PIsAlniK, P. KośCIŃKI, Dom Polski zabrany, s. A10; J. BIELECKI, Polska chce od Unii ultimatum dla Mińska, „Dziennik Gazeta Prawna" 18 II 2010, nr 34, s. A2; Sprawozdanie stenograficzne z 61. posiedzenia Sejmu RP w dn. 18 II 2010, wypowiedź Jana Borkowskiego.

${ }^{69}$ P. WroŃsKi, MSZ ostrzega Mińsk, s. 11; Kancelaria Sejmu, Biuletyn nr 3471/VI z posiedzenia Komisji Łączności z Polakami za Granicą oraz Komisji Spraw Zagranicznych w dn. 26 II 2010 [da- 
uległ zahamowaniu. Problemy ZPB omawiane były 22 lutego 2010 r. przez unijnych ministrów spraw zagranicznych ${ }^{70}$. Podczas posiedzenia, na którym obecny był minister Sikorski, nie został poruszony temat sankcji, jakie Bruksela mogłaby zastosować w odpowiedzi na represjonowanie Polaków. Szefowie dyplomacji zobowiązali się jedynie do stałego monitorowania rozwoju sytuacji $\mathrm{ZPB}^{71}$.

W obliczu zaistniałych napięć, jak też braku reakcji strony białoruskiej na przedstawiane jej groźby, rząd Donalda Tuska nie zdecydował się również na przerwanie rozwoju dwustronnego dialogu. Mimo iż przestrzeganie praw polskiej mniejszości, w tym jej głównej organizacji, niezmiennie określano jako podstawowy warunek zbliżenia Polski z Białorusią, w kierowanym przez R. Sikorskiego MSZ, wydarzenia z początku $2010 \mathrm{r}$. uznano za niedostateczny powód do zmiany przyjętej strategii. Wynikało to z oceny, iż skala zaistniałych represji była o wiele mniejsza od tej, jaka miała miejsce w okresie utrzymywania przez Warszawę izolacji Mińska. Przedstawiciel MSZ w połowie lutego 2010 r. przekonywał z trybuny sejmowej: „Z największym nasileniem represji wobec mniejszości polskiej [...] mieliśmy do czynienia wtedy, kiedy nie było dialogu z Białorusią, od 2005 r. przez 2006 r., kiedy odebrano Związkowi Polaków na Białorusi 14 domów polskich, kiedy zamknięto niezależne wydawnictwa mniejszości polskiej i kiedy odbywały się liczne aresztowania i sfingowane procesy sądowe"72. W odczuciu resortu dyplomacji, po nawiązaniu kontaktów z władzami Białorusi w 2007 r., wokół organizacji polskiej mniejszości zapanował względny spokój. Dialog nie doprowadził wprawdzie do zalegalizowania uznawanego w Warszawie ZPB, jednak organizacja ta mogła wypełniać swe statutowe cele. Przedstawiciel MSZ przypominał również, iż białoruskie władze umożliwiły przeprowadzenie Zjazdu, podczas którego Andżelika Borys ponownie została wybrana na prezesa. Dzięki temu wspierany przez Polskę zarząd utrzymał swą demokratyczną legitymację ${ }^{73}$.

lej: Biuletyn nr 3471/VI], wypowiedź Macieja Szymańskiego; RICZ, PW, Bruksela ostrzega Mińsk, „Gazeta Wyborcza” 17 II 2010, nr 40, s. 11.

70 J. BIELECKI, Polska chce od Unii ultimatum dla Mińska, s. A2; I. DudzIK, Polska chce jednego głosu Unii, „Dziennik Gazeta Prawna” 22 II 2010, nr 36, s. A6; Sprawozdanie stenograficzne z 61. posiedzenia Sejmu RP w dn. 18 II 2010, wypowiedź Jana Borkowskiego. Zob. też M. BorowsKi, 7 propozycji, pieniadze i wspólny głos, „Gazeta Wyborcza” 24 II 2010, nr 46, s. 16; Kancelaria Sejmu, Biuletyn nr 3471/VI, wypowiedź Macieja Szymańskiego.

71 J. BieleCKi, K. WronowsKa, Tylko Litwini i Ashton poparli pomysty Sikorskiego, „Dziennik Gazeta Prawna” 23 II 2010, nr 37, s. A3.

${ }^{72}$ Sprawozdanie stenograficzne z 61. posiedzenia Sejmu RP w dn. 18 II 2010, wypowiedzi Jana Borkowskiego. Zob. też Sprawozdanie stenograficzne z 64. posiedzenia Sejmu RP w dn. 8 IV 2010, wypowiedź Radosława Sikorskiego.

${ }^{73}$ Sprawozdanie stenograficzne z 61. posiedzenia Sejmu RP w dn. 18 II 2010, wypowiedzi Jana Borkowskiego. 
Sens kontynuowania dialogu z białoruskimi władzami tłumaczony był również względami geopolitycznymi. W resorcie dyplomacji przyjęto, iż konflikt Warszawy i Mińska, spowodowany problemami polskiej mniejszości, służył interesom Rosji. Stanowisko takie podczas posiedzenia senackiej Komisji Spraw Emigracji i Łączności z Polakami za Granicą zaprezentował dyrektor Departamentu Wschodniego w MSZ Jarosław Bratkiewicz:

[...] o ile wcześniej Białoruś była krajem, można użyć takiego określenia, przyklejonym na trwałe do Rosji, o tyle teraz wykazuje pewne autonomiczne ruchy, ruchy wahadłowe, ruchy oscylowania pomiędzy Rosją a światem zachodnim. Uważamy, że jest to ważny przejaw $[\ldots]$ odradzania się $[\ldots]$ tożsamości białoruskiej. Jest to zgodne z naszymi wyobrażeniami pozytywnych procesów, które powinny dokonywać się w tak zwanej przestrzeni postsowieckiej, czyli procesów uzyskiwania przez narody i państwa znajdujące się w tej przestrzeni swojej podmiotowości, swojej autonomii politycznej. [...] Ten proces większej czy postępującej emancypacji podmiotowości białoruskiej nie może nie wzbudzać określonych reakcji u wielkiego sąsiada Białorusi. Myślę, że na pewno jest to postrzegane jako pewnego rodzaju poważne, nazwijmy to, wyzwanie natury geopolitycznej. Sam fakt, że Białoruś włączyła się do inicjatywy Partnerstwa Wschodniego, jest przyjmowany jako jeden z elementów nowego wyzwania przez Rosję. Sprawa naszej mniejszości powinna być również postrzegana w kontekście tych dużych [...] zjawisk politycznych zachodzących wokół Białorusi ${ }^{74}$.

Przedstawiciel MSZ przekonywał, iż Rosja była zainteresowana utrudnieniem procesu zbliżania Białorusi do Europy. Konflikt wokół polskiej mniejszości stwarzał natomiast dogodną sytuację do skompromitowania w oczach zachodnich przywódców, deklarujących wewnętrzną liberalizację białoruskich władz. Jarosław Bratkiewicz wyjaśniał: „Sprawa mniejszości polskiej ze względów jak najbardziej naturalnych leży głęboko w umysłach i sercach polskiej klasy politycznej. Jest to znakomita sposobność, żeby wywołać określone emocje w Polsce i właśnie poprzez Polskę [...] starać się w szczególności skompromitować Białoruś i zachęcić Polskę do wyrażenia na forum unijnym wątpliwości odnośnie do perspektywiczności [...] ustanawiania powiązań z Białorusią"75. Wobec powyższych argumentów w kierowanym przez R. Sikorskiego resorcie uznano, iż w krótkim czasie powinien zostać osiągnięty kompromis w sprawie $\mathrm{ZPB}^{76}$.

74 Kancelaria Senatu, Zapis stenograficzny z 56. posiedzenia Komisji Spraw Emigracji i Łączności z Polakami za Granicą w dn. 16 II 2010, wypowiedź Jarosława Bratkiewicza.

75 Tamże, wypowiedź Jarosława Bratkiewicza. Zob. też J.M. NowAKowski, Trudna pomoc, „Newsweek” 7 II 2010, nr 6, s. 51.

${ }^{76}$ Kancelaria Senatu, Zapis stenograficzny z 56. posiedzenia Komisji Spraw Emigracji i Łączności z Polakami za Granicą w dn. 16 II 2010, wypowiedź Jarosława Bratkiewicza. 


\section{PRÓBA ROZWIĄZANIA SPORU W ZPB PO WYDARZENIACH WOKÓŁ DOMU POLSKIEGO W IWIEŃCU}

Do kompromisu w kwestii ZPB Warszawa zamierzała dążyć poprzez „rozmowy na wysokim szczeblu politycznym oraz dyrektorsko-eksperckim" "77. Celem polskich dyplomatów było doprowadzenie do odzyskania przez Andżelikę Borys Domu Polskiego w Iwieńcu, jak też ważnych dla jej organizacji obiektów, zajętych w poprzednich latach przez Józefa Łucznika ${ }^{78}$. Podczas podjętych negocjacji Warszawa zastosowała tę samą metodę, jak przed Zjazdem ZPB w 2009 r. Od postawy Mińska wobec organizacji Andżeliki Borys uzależniono wsparcie dla białoruskich interesów na Zachodzie.

Rozmowy z wysokiej rangi reprezentantem białoruskich władz odbyły się już 12 lutego 2010 r. Wizytę w Warszawie złożył wówczas minister spraw zagranicznych Siergiej Martynow. Według wcześniejszych ustaleń, celem jego przyjazdu miało być przede wszystkim pogłębienie kontaktów gospodarczych i społecznych $^{79}$. Ze względu na wydarzenia wokół iwienieckiego oddziału ZPB, w Polsce pojawiły się wątpliwości, czy wizyta ta powinna dojść do skutku. Ostatecznie nie zdecydowano się jednak na jej odwołanie. Radosław Sikorski postanowił wykorzystać spotkanie z przedstawicielem Białorusi do wypracowania porozumienia w kwestii ZPB. Szef polskiej dyplomacji przekazał wówczas Siergiejowi Martynowowi list adresowany do Aleksandra Łukaszenki. Zawarty w nim został wykaz kilkunastu korzystnych dla Białorusi spraw na arenie międzynarodowej, które mogły zostać zrealizowane przy pomocy Polski ${ }^{80}$. Zaliczono do nich m.in. uzyskanie pożyczek od Rady Państw Morza Bałtyckiego oraz Rady Europy, kolejną transzę kredytu z MFW, objęcie Białorusi programami Organizacji Współpracy Gospodarczej i Rozwoju, zniesienie unijnych sankcji wizowych, uruchomienie niektórych programów Partnerstwa Wschodniego, przywrócenie przez UE ogólnego syste-

77 Kancelaria Sejmu, Biuletyn nr 3329/VI, wypowiedź Jana Borkowskiego.

${ }^{78}$ Sprawozdanie stenograficzne z 61. posiedzenia Sejmu RP w dn. 18 II 2010, wypowiedź Jana Borkowskiego. Według informacji przekazywanych przez Jana Borkowskiego, kwestia domów polskich od początku zajmowała istotne miejsce w polsko-białoruskich rozmowach dotyczących ZPB. Celem polskich negocjatorów w rokowaniach z przedstawicielami białoruskich władz było doprowadzenie do odzyskania przez demokratycznie wyłonione kierownictwo tych budynków, które były istotne z punktu widzenia społecznej działalności związku, jak też niedopuszczenie do utraty pozostałych.

79 Kancelaria Senatu, Zapis stenograficzny z 56. posiedzenia Komisji Spraw Emigracji i Łączności z Polakami za Granicą w dn. 16 II 2010, wypowiedź Jarosława Bratkiewicza. Zwieńczeniem wizyty miało być podpisanie umowy o małym ruchu granicznym.

${ }^{80}$ Sprawozdanie stenograficzne z 61. posiedzenia Sejmu RP w dn. 18 II 2010, wypowiedź Jana Borkowskiego. 
mu preferencji handlowych dla Białorusi (GSP), jak też wznowienie na poziomie Wspólnoty procesu negocjacji nad przystąpieniem Białorusi do Światowej Organizacji Handlu ${ }^{81}$. Według informacji przedstawicieli MSZ, w sytuacji negatywnego rozwoju wydarzeń wokół ZPB, Polska mogła nie tylko wycofać swoje wsparcie dla tych spraw, ale też doprowadzić do ich rozstrzygnięcia na niekorzyść Białorusi ${ }^{82}$.

Spotkanie ministrów spraw zagranicznych nie doprowadziło do automatycznego zahamowania represji wobec organizacji polskiej mniejszości, ani tym bardziej zwrócenia jej utraconego majątku. Cytowany anonimowo przez „Gazetę Wyborczą" polski dyplomata informował, iż lokalne władze realizowały scenariusz ustalony jeszcze przed wizytą S. Martynowa w Polsce. Plan ten nie został odwołany ze względu na niemożność skontaktowania się szefa białoruskiej dyplomacji z Aleksandrem Łukaszenką, który przebywał wówczas w Szwajcarii na nartach. Według doniesień prasowych, ambasador Białorusi przekonywał polskie MSZ, iż wkrótce władze lokalne zostaną zobowiązane do zmniejszenia presji na Andżelikę Borys ${ }^{83}$.

Wychodząc z założenia, iż jedyną osobą na Białorusi mogącą doprowadzić do ostatecznego rozwiązania problemu ZPB był Aleksander Łukaszenko, Radosław Sikorski podjął decyzję o przeprowadzeniu z nim osobistej rozmowy. Spotkanie wysokiej rangi przedstawiciela Polski z białoruskim prezydentem budziło pewne kontrowersje. Szef resortu dyplomacji swoją decyzję tłumaczył w następujący sposób: „na rzecz Polaków na Białorusi jestem gotów podjąć osobiste ryzyko polityczne figurowania na fotkach z Aleksandrem Łukaszenką"84. Według Sikorskiego, przedstawienie osobie, która „decydujące o wszystkim na Białorusi” konsekwencji, jakie przyniosą jej decyzje w kwestii ZPB dla stosunków z Polską, dawało realną szansę na zahamowanie wrogich działań oraz definitywne rozwiązanie ciągnącego się od pięciu lat sporu ${ }^{85}$.

${ }^{81}$ K. Zuchowicz, A. Pisalnik, Białoruś ustyszała warunki, „Rzeczpospolita” 13-14 II 2010, nr 37, s. A8; P. Wroński, Warszawa ostrzega Mińsk, „Gazeta Wyborcza” 13-14 II 2010, nr 37, s. 1; P. WroŃsKi, List do Łukaszenki, „Gazeta Wyborcza” 13-14 II 2010, nr 37, s. 3; Sprawozdanie stenograficzne z 61. posiedzenia Sejmu RP w dn. 18 II 2010, wypowiedź Jana Borkowskiego.

82 Kancelaria Senatu, Zapis stenograficzny z 56. posiedzenia Komisji Spraw Emigracji i Łączności z Polakami za Granicą w dn. 16 II 2010, wypowiedź Macieja Szymańskiego; Sprawozdanie stenograficzne z 61. posiedzenia Sejmu RP w dn. 18 II 2010 , wypowiedź Jana Borkowskiego.

${ }^{83}$ Zaledwie kilka dni po wizycie białoruskiego ministra spraw zagranicznych w Warszawie grupa działaczy ZPB trafiła do aresztu. Zob. P. Wroński, MSZ ostrzega Mińsk, s. 11.

${ }^{84}$ Sprawozdanie stenograficzne z 64. posiedzenia Sejmu RP w dn. 8 IV 2010, wypowiedź Radosława Sikorskiego. Zob. też Kancelaria Sejmu, Biuletyn nr 3632/VI, wypowiedź Radosława Sikorskiego.

${ }^{85}$ R. Sikorski, Opinie, „Rzeczpospolita” 26 II 2010, nr 48, s. A10; R. Grochal, B.T. WieliŃSKI, Łukaszenka mięknie?, „Gazeta Wyborcza” 26 II 2010, nr 48, s. 10. 
Okazją do rozmowy R. Sikorskiego z A. Łukaszenką stało się zaprzysiężenie prezydenta Ukrainy Wiktora Janukowycza 25 lutego 2010 r. ${ }^{86}$ Podczas zaaranżowanego w Kijowie spotkania minister przedstawił białoruskiemu prezydentowi polski punkt widzenia na sytuację związaną z Domem Polskim w Iwieńcu. Opisał również działania, jakie mogły zostać podjęte w przypadku narastania represji ${ }^{87}$. Jako ostateczny sposób unormowania położenia ZPB, minister Sikorski zaproponował tzw. opcję zerową. Zakładała ona uznanie przez Mińsk obu związków oraz równy podział istniejącego majątku. Organizacje kierowane przez Stanisława Siemaszkę oraz Andżelikę Borys otrzymałyby po osiem domów polskich ${ }^{88}$. Taką samą ofertę Sikorski przekazał w Kijowie Martynowowi ${ }^{89}$. Efektem przeprowadzonych rozmów stała się decyzja o powołaniu polsko-białoruskiej grupy roboczej, mającej doprowadzić do rozwiązania sprawy ZPB ${ }^{90}$. Siergiej Martynow został zobowiązany do stałego informowania Aleksandra Łukaszenki o postępach w negocjacjach ${ }^{91}$.

Pierwsze posiedzenie polsko-białoruskiej komisji odbyło się 19 marca $2010 \mathrm{r}$. w Mińsku ${ }^{92}$. Na czele polskich negocjatorów stanął wiceminister spraw zagranicznych Andrzej Kremer. Stronę białoruską reprezentował pełnomocnik rządu ds. religii i narodowości Leanid Hulaka ${ }^{93}$. Polscy dyplomaci jako rozwiązanie alternatywne wobec anulowania decyzji Ministerstwa Sprawiedliwości o unieważnieniu wyników VI Zjazdu ZPB, forsowali tzw. opcję zerową. Po zarejestrowaniu dwóch niezależnych organizacji oraz podziale majątku ZPB, Polska zniosłaby sankcje wizowe nałożone na przedstawicieli organizacji Stanisława Siemaszki ${ }^{94}$. Efekty pierwszego posiedzenia dwustronnej komisji nie zostały przekazane opinii publicz-

${ }^{86}$ Sikorski postanowił uczestniczyć w tej uroczystości właśnie ze względu na możliwość bezpośredniego spotkania z prezydentem Łukaszenką. Zob. W. LoREnz, P. Kościński, Sikorski negocjuje z Łukaszenka, „Rzeczpospolita” 26 II 2010, nr 48, s. A10; M. ZIARNIK, Sikorski zawiedziony rozmowa z Eukaszenkq, „Nasz Dziennik” 26 II 2010, nr 48, s. 11.

${ }^{87}$ Kancelaria Sejmu, Biuletyn nr 3471/VI, wypowiedź Macieja Szymańskiego.

${ }^{88}$ R. Grochal, B.T. Wieliński, Łukaszenka mięknie?, s. 10. Kancelaria Sejmu, Biuletyn nr 3632/VI, wypowiedź Radosława Sikorskiego; Kancelaria Sejmu, Biuletyn nr 3329/VI, wypowiedź Jana Borkowskiego i Marka Borowskiego.

89 M. GracZYK, Lukaszenka: to moi Polacy i sami chcieli więzienia, „Dziennik Gazeta Prawna” 26-28 II 2010, nr 40, s. A3.

${ }^{90}$ W. LoRENZ, P. KościŃSKI, Sikorski negocjuje z Łukaszenka, s. A10.

91 R. Grochal, B.T. WieLińsKi, Łukaszenka mięknie?, s. 10.

${ }_{92}$ Pierwotnie posiedzenie zostało zaplanowane na 9 marca $2010 \mathrm{r}$. Termin ten został następnie przełożony. Zob. MBZ, PAP, Posiedzenie w sprawie ZPB odłożone, „Nasz Dziennik” 10 III 2010, nr 58, s. 7.

${ }^{93}$ P. Kościński, A. Pisalnik, Szansa dla pani Borys?, „Rzeczpospolita” 20-21 III 2010, nr 67, s. A12.

${ }^{94}$ RIM, Zaczęli negocjacje o Polakach na Białorusi, „Gazeta Wyborcza” 20-21 III 2010, nr 67, s. 9. 
nej. Kierujący pracami polskich dyplomatów Andrzej Kremer 10 kwietnia 2010 r. zginął w katastrofie lotniczej pod Smoleńskiem.

Do końca 2010 r. nie odbyło się kolejne posiedzenie dwustronnej komisji. Polskie władze winą za brak postępów w negocjacjach obarczały stronę białoruską ${ }^{95}$. Wydaje się jednak, iż w szeregach rządu zapadła decyzja o wyciszeniu problemów ZPB. Prasa donosiła, iż 20 kwietnia 2010 r. w Białymstoku pojawili się członkowie nieuznawanego przez Polskę zarządu, którzy wcześniej objęci byli sankcjami wizowymi ${ }^{96}$. W czerwcu 2010 r., po nienagłaśnianej wizycie podsekretarza stanu w MSZ Henryka Litwina w Grodnie, Andżelika Borys, powołując się na względy osobiste, zapowiedziała rezygnację ze sprawowanej funkcji ${ }^{97}$. Rada Naczelna pełnienie obowiązków prezesa ZPB powierzyła Andżelice Orechwo ${ }^{98}$.

Ostatnia próba doprowadzenia do rozwiązania problemu ZPB w drodze rozmów z białoruskimi władzami została podjęta 2 listopada 2010 r. Polski minister spraw zagranicznych, w towarzystwie swego niemieckiego odpowiednika, złożył wówczas wizytę w Mińsku. Podczas spotkania z szefem Administracji Prezydenta Białorusi Radosław Sikorski podjął temat polskiej organizacji ${ }^{99}$. Przebieg tej rozmowy nie został oficjalnie ujawniony. Efekty zabiegów dyplomatów o legalizację wspieranego przez Warszawę zarządu ZPB obrazują natomiast wypowiedzi A. Łukaszenki w wywiadzie udzielonym na początku listopada 2010 r. dla polskich dziennikarzy. Białoruski prezydent zadeklarował w nim, iż w jego państwie nie mogą istnieć dwie organizacje o tej samej nazwie. Zarejestrowane stowarzyszenie Związek Polaków na Białorusi kierowane było przez S. Siemaszkę. Grupa Polaków, która nie chciała uznać jego władzy, miała natomiast prawo do złożenia w Ministerstwie Sprawiedliwości wniosku o zarejestrowanie innej organizacji. Jednocześnie A. Łukaszenko wyraził sceptycyzm wobec sensowności powoływania kilku polskich stowarzyszeń. Wyjaśniał, iż prowadziłyby one ze sobą niepotrzebną rywalizację. W tym samym wywiadzie winą za cały konflikt wokół ZPB prezydent obarczył Andżelikę Borys, która w jego odczuciu zamiast prowadzić działalność kulturalną zajęła się polityką, stając się wraz ze swymi stronnikami siłą opozycyjną ${ }^{100}$. W reakcji na ten wywiad

${ }^{95}$ Kancelaria Sejmu, Biuletyn nr 4585/VI z posiedzenia Komisji Spraw Zagranicznych w dn. 19 I 2011, wypowiedź Henryka Litwina.

${ }^{96}$ P. KośCIŃSKI, Wizy dla ZPB w drodze wyjątku?, „Rzeczpospolita” 21 IV 2010, nr 93, s. A12.

97 A. PIsalnik, P. KościńsKi, Andżelika Borys rezygnuje, „Rzeczpospolita” 14 VI 2010, nr 136, s. A11; MZ, Dymisja Borys, „Gazeta Wyborcza” 14 VI 2010, nr 136, s. 1.

98 A. PisalniK, Andżelika zastępuje Andżelikę, ,Rzeczpospolita” 21 VI 2010, nr 142, s. A15; JAP, Nowa szefowa Zwiąku Polaków, „Gazeta Wyborcza” 21 VI 2010, nr 142, s. 15.

99 A. Poczoвut, Trzy miliardy euro za demokracje, „Gazeta Wyborcza” 3 XI 2010, nr 257, s. 9.

${ }_{100}$ Łukaszenko: Nie dzielcie moich Polaków, rozmowę przeprowadził P. Kościński, „Rzeczpospolita" 6-7 XI 2010, nr 260, s. A10. 
Rada Naczelna nieuznawanego na Białorusi ZPB podjęła decyzję o odrzuceniu oferty zarejestrowania swej organizacji pod inną nazwą ${ }^{101}$. Oznaczało to, iż podejmowane przez ponad dwa lata zabiegi na rzecz kompromisowego rozwiązania problemu Związku Polaków na Białorusi zakończyły się niepowodzeniem.

\section{PODSUMOWANIE}

Przerywając pod koniec 2007 r. izolację Mińska, rząd Donalda Tuska deklarował gotowość do pogłębienia dwustronnych relacji, pod warunkiem poprawy położenia polskiej mniejszości narodowej. Mimo iż główne problemy tej grupy pozostawały nierozwiązane, dialog kontynuowany był przez trzy lata. Mając na celu uniezależnienie wschodniego sąsiada od Rosji, Warszawa w rzeczywistości unikała zakłócania procesu unijno-białoruskiego zbliżenia napięciami związanymi z polską mniejszością. Zakończenie dialogu nastąpiło dopiero w drugiej połowie grudnia 2010 r., na skutek sfałszowania przez białoruskie władze wyborów prezydenckich oraz brutalnego rozprawienia się z protestującymi opozycjonistami. Po tych wydarzeniach zdominowany przez PO rząd skoordynował swą politykę wobec Białorusi ze strategią przyjętą przez całą UE. Zakładała ona natomiast rezygnację z dalszych prób dialogu z Aleksandrem Łukaszenką.

W kolejnych latach polskie władze utrzymały poparcie wyłącznie dla demokratycznie wyłonionego zarządu ZPB ${ }^{102}$. Kierowany przez Radosława Sikorskiego MSZ, po $2010 \mathrm{r}$. nie zaprezentował już żadnego pomysłu na rozwiązanie trwającego od 2005 r. kryzysu. Wyrazem swoistej bezsilności był apel Sikorskiego z początku stycznia 2011 r., aby „nie udawać, że ktoś ma jakąś cudowną receptę na to, jak pomóc ZPB czy jak zmienić postępowanie władz białoruskich wobec związku"103. Po 2010 r. w debacie publicznej sytuację polskiej organizacji na Białorusi powszechnie oceniano jako jeden z przejawów łamania w tym państwie praw człowieka oraz praw obywatelskich. Dominująca stała się opinia, iż mniejszość polska będzie mogła cieszyć się pełnią praw tylko w wolnej i demokratycznej Białorusi ${ }^{104}$.

101 A. PISAlnik, Polacy wola być nielegalni, „Rzeczpospolita” 29 XI 2010, nr 278, s. A11.

102 Kancelaria Sejmu, Biuro Komisji Sejmowych, Pełny zapis przebiegu 24. posiedzenia Komisji Łączności z Polakami za Granicą w dn. 24 X 2012, wypowiedź Janusza Ciska; Sprawozdanie stenograficzne z 87. posiedzenia Sejmu RP w dn. 16 III 2011, wypowiedź Radosława Sikorskiego.

${ }^{103}$ Kancelaria Sejmu, Biuletyn nr 4557/VI z posiedzenia Komisji Spraw Zagranicznych w dn. 4 I 2011, wypowiedź Radosława Sikorskiego.

${ }^{104}$ Kancelaria Senatu, Zapis stenograficzny z 40. posiedzenia Komisji Spraw Emigracji i Łączności z Polakami za Granicą w dn. 2 VII 2013, wypowiedź Katarzyny Pełczyńskiej-Nałęcz; Kancelaria Sejmu, Biuletyn nr 4974/VI z posiedzenia Komisji Łączności z Polakami za Granicą w dn. 15 IV 


\section{BIBLIOGRAFIA}

\section{Źródła}

\section{Archiwalia}

Archiwum Sejmu Rzeczypospolitej Polskiej

Biuletyn nr 4615/IV z posiedzenia Komisji Łączności z Polakami za Granicą oraz Komisji Spraw Zagranicznych w dn. 20 V 2005.

Biuletyn nr 1074/VI z posiedzenia Komisji Łączności z Polakami za Granicą w dn. 3 IX 2008.

Biuletyn nr 1227/VI z posiedzenia Komisji Spraw Zagranicznych oraz Komisji Łączności z Polakami za Granicą w dn. 2 X 2008.

Biuletyn nr 1339/VI z posiedzenia Komisji Łączności z Polakami za Granicą w dn. 15 X 2008.

Biuletyn nr 2747/VI z posiedzenia Komisji Spraw Zagranicznych w dn. 23 IX 2009.

Biuletyn nr 3303/VI z posiedzenia Komisji Łączności z Polakami za Granicą w dn. 21 I 2010.

Biuletyn nr 3329/VI z posiedzenia Komisji Łączności z Polakami za Granicą w dn. 22 I 2010.

Biuletyn nr 3406/VI z posiedzenia Komisji Łączności z Polakami za Granicą oraz Komisji Spraw Zagranicznych w dn. 11 II 2010.

Biuletyn nr 3471/VI z posiedzenia Komisji Łączności z Polakami za Granicą oraz Komisji Spraw Zagranicznych w dn. 26 II 2010.

Biuletyn nr 3632/VI z posiedzenia Komisji Spraw Zagranicznych w dn. 7 IV 2010.

Biuletyn nr 4557/VI z posiedzenia Komisji Spraw Zagranicznych w dn. 4 I 2011.

Biuletyn nr 4585/VI z posiedzenia Komisji Spraw Zagranicznych w dn. 19 I 2011.

Biuletyn nr 4974/VI z posiedzenia Komisji Łączności z Polakami za Granicą w dn. 15 IV 2011.

Pełny zapis przebiegu 24. posiedzenia Komisji Łączności z Polakami za Granicą w dn. 24 X 2012.

Sprawozdanie stenograficzne z 35. posiedzenia Sejmu RP w dn. 13 II 2009.

Sprawozdanie stenograficzne z 39. posiedzenia Sejmu RP w dn. 2 IV 2009.

Sprawozdanie stenograficzne z 61. posiedzenia Sejmu RP w dn. 18 II 2010.

Sprawozdanie stenograficzne z 62. posiedzenia Sejmu RP w dn. 4 III 2010.

Sprawozdanie stenograficzne z 64. posiedzenia Sejmu RP w dn. 8 IV 2010.

Sprawozdanie stenograficzne z 85. posiedzenia Sejmu RP w dn. 24 II 2011.

Sprawozdanie stenograficzne z 87. posiedzenia Sejmu RP w dn. 16 III 2011.

2011, wypowiedź Roberta Tyszkiewicza; Kancelaria Sejmu, Biuletyn nr 3406/VI, wypowiedź Artura Górskiego; J. Bielecki, Polska chce pomóc Łukaszence, „Dziennik Polska Europa Świat” 14-15 III 2009, nr 62, s. 4; Sprawozdanie stenograficzne z 85. posiedzenia Sejmu RP w dn. 24 II 2011, wypowiedź Roberta Tyszkiewicza; Sprawozdanie stenograficzne z 11. posiedzenia Sejmu RP w dn. 29 III 2012, wypowiedź Roberta Tyszkiewicza. 
Sprawozdanie stenograficzne z 11. posiedzenia Sejmu RP w dn. 29 III 2012.

Odpowiedź podsekretarz stanu w MSZ z upoważnienia prezesa Rady Ministrów na interpelację nr 9994 w sprawie realizacji zadań przez Departament Współpracy z Polonią MSZ, kadencja VII.

Archiwum Senatu Rzeczypospolitej Polskiej

Zapis stenograficzny z 56. posiedzenia Komisji Spraw Emigracji i Łączności z Polakami za Granicą w dn. 16 II 2010.

Zapis stenograficzny z 40. posiedzenia Komisji Spraw Emigracji i Łączności z Polakami za Granicą w dn. 2 VII 2013.

Archiwum Rady Ministrów Kancelarii Prezesa Rady Ministrów

Sekretariat Prezesa Rady Ministrów Donalda Tuska, Rządowe programy współpracy z zagranicą 2009.

Dokumenty Ministerstwa Spraw Zagranicznych

Raport o sytuacji Polonii i Polaków za granicą 2009, red. K. Sawicki i zespół pracowników Departamentu Współpracy z Polonią MSZ, Warszawa 2009.

Stanowisko Ministerstwa Spraw Zagranicznych wobec sytuacji Związku Polaków na Białorusi, 2005 IX 6, www.msz.gov.pl.

\section{Literatura wspomnieniowa}

GAwIN T., Związek Polaków na Białorusi. Historia niszczenia niezależności 1988-2005, Białystok: Rada Programowa Tygodnika NIWA 2006.

\section{Literatura przedmiotu}

Gawin T., Polskie odrodzenie na Białorusi 1988-2005, Białystok: Wyższa Szkoła Administracji Publicznej im. Stanisława Staszica 2010.

MikoŁajczaK S., Polacy na Białorusi w latach 1987-2008. Funkcjonowanie organizacji mniejszości polskiej w systemie politycznym, Poznań: Wydawnictwo Wyższej Szkoły Bezpieczeństwa 2013.

WŁodarczyK A., Polskie środowiska polityczne wobec konfliktu w stosunkach polsko-białoruskich w 2005 roku, „Studia Podlaskie” 20(2012).

\section{Prasa}

„Dziennik Gazeta Prawna” 2010

„Dziennik Polska Europa Świat” 2008-2010

„Gazeta Wyborcza” 2005, 2008-2010

„Nasz Dziennik” 2010

„Newsweek” 2010

„Polityka” 2008

„Rzeczpospolita” 2000, 2005, 2008-2010

„Trybuna” 2009

„Tydzień na Wschodzie” 2009-2010 


\section{ZWIĄZEK POLAKÓW NA BIAŁORUSI W POLSKIEJ POLITYCE ZAGRANICZNEJ W LATACH 2008-2010}

\section{Streszczenie}

Po przejęciu władzy w Polsce przez Platformę Obywatelską w 2007 r., nastąpiła zmiana polskiej polityki zagranicznej wobec Białorusi. Gabinet Donalda Tuska postanowił nawiązać oficjalne kontakty z członkami białoruskiego rządu. Najtrudniejszą barierą dla poprawy stosunków dwustronnych był podział w Związku Polaków na Białorusi. Ministerstwo Spraw Zagranicznych postanowiło rozwiązać ten problem tak, aby białoruski rząd mógłby go zaakceptować. W 2008 r. Polscy dyplomaci podjęli poufne rozmowy ze swoimi białoruskimi odpowiednikami na temat polskiej mniejszości. Negocjatorzy postanowili stworzyć dwustronny zespół roboczy, który musiał znaleźć rozwiązanie konfliktu wokół Związku Polaków na Białorusi. Polska zadeklarowała, że pogłębienie stosunków dwustronnych zależy od poprawy sytuacji polskiej mniejszości narodowej. Mimo że główny problem tej grupy pozostał nierozwiązany, dialog trwał trzy lata. Rzeczywiście, Polska uniknęła zakłócania dialogu, który był prowadzony między Białorusią a Unią Europejską. Jego celem było zmniejszenie zależności Białorusi od Rosji. Polska zakończyła kontakty z białoruskimi urzędnikami w grudniu $2010 \mathrm{r}$. Powodem tego nie były nierozwiązane problemy polskiej mniejszości, ale oszustwo w wyborach prezydenckich na Białorusi i brutalne stłumienie protestu opozycji.

Słowa kluczowe: polska mniejszość na Białorusi; Związek Polaków na Białorusi; Polska polityka zagraniczna

\section{UNION OF POLES IN BELARUS IN THE POLISH FOREIGN POLITICS DURING THE YEARS 2008-2010}

\section{Summary}

Taking power in Poland by Civil Platform in 2007 was followed by a change in the Polish foreign politics toward Belarus. Donald Tusk`s cabinet decided to make official contacts with members of Belarusian government. The most difficult barrier to improving bilateral relations was division in the Union of Poles in Belarus. Ministry of Foreign Affairs decided to resolve this problem in way that could be accepted by Belarusian government. In 2008 Polish diplomats took confidential conversations with their Belarusian counterparts about Polish minority. Negotiators decided to create bilateral work team, which was bound to found a resolution of conflict around the Union of Poles in Belarus. Poland declared that deepening of bilateral relations depends on improving situation of Polish national minority. In spite of the main problem of this group remained unresolved, dialogue was being continued for three years. Indeed, Poland avoided disrupting dialogue which was conducted between Belarus and European Union. Its target was to reduce Belarusian dependences on Russia. Poland finished contacts with Belarusian officials in December 2010. The reason for that were not unresolved problems of Polish minority, but instead the fraud in presidential election in Belarus and brutal suppression of the opposition protest.

Key words: Polish minority in Belarus; Union of Poles in Belarus; Polish foreign politics 